\title{
SHELLEY IN THE TRANSITION TO RUSSIAN SYMBOLISM: \\ THREE VERSIONS OF 'OZYMANDIAS'
}

\author{
David N. Wells
}

\section{I}

Shelley is a particularly significant figure in the early development of Russian Symbolism because of the high degree of critical attention he received in the 1880s and 1890s when Symbolism was rising as a literary force in Russia, and because of the number and quality of his translators. This article examines three different translations of Shelley's sonnet 'Ozymandias' from the period. Taken together, they show that the English poet could be interpreted in different ways in order to support radically different aesthetic ideas, and to reflect both the views of the literary establishment and those of the emerging Symbolist movement. At the same time the example of Shelley confirms a persistent general truth about literary history: that the literary past is constantly recreated in terms of the present, and that a shared culture can be used to promote a changing view of the world as well as to reinforce the status quo.

The advent of Symbolism as a literary movement in Russian literature is sometimes seen as a revolution in which a tide of individualism, prompted by a crisis of faith at home, and combined with a new sense of form drawing on French models, replaced almost overnight the positivist and utilitarian traditions of the 1870s and 1880s with their emphasis on social responsibility and their more conservative approach to metre, rhyme and poetic style. ${ }^{1}$ And indeed three landmark literary events marking the advent of Symbolism in Russia occurred in the pivotal year of 1892 - the publication of Zinaida Vengerova's groundbreaking article on the French Symbolist poets in Severnyi vestnik, the appearance of

\footnotetext{
${ }^{1}$ Ronald E. Peterson, A History of Russian Symbolism (Amsterdam: J. Benjamins, 1993), pp. 13-26. See also Avril Pyman, A History of Russian Symbolism (Cambridge: Cambridge University Press, 1994), pp. 1-2.
} 
Dmitrii Merezhkovskii's verse collection Simvoly [Symbols], and his lectures 'O prichinakh upadka i o novykh techeniiakh v sovremennoi russkoi literature' [The Reasons for the Decline and the New Currents in Contemporary Russian Literature]. They were followed very rapidly over the next few years by a series of works by Merezhkovskii himself, Zinaida Hippius, Fedor Sologub, Aleksandr Dobroliubov, Konstantin Bal'mont, Valerii Briusov and others, which changed the literary agenda beyond recognition.

As with other revolutions, however, there was in reality no complete break between the old and the new. The literary education and backgrounds of representatives of the positivist tradition and early proponents of the 'new art' were often very similar. During the transitional period of the 1890s, indeed, writers not infrequently changed their allegiance from one side to the other. Several prominent literary figures began their careers as followers of the populist movement, later to become pioneers of Symbolism. At the outset of his career Merezhkovskii, for example, was strongly influenced by the populists Semen Nadson, Nikolai Mikhailovskii and Gleb Uspenskii. ${ }^{2}$ Merezhkovskii’s first book of verse, published in 1888 and informed by his extensive travels to rural Russia in the mid-1880s, substantially follows the civic tradition and was well received by positivist critics. Simvoly, his second book, as the title suggests, aligns itself very firmly with the emerging movement. ${ }^{3}$ Nikolai Minskii was another poet who, seeking to translate civic issues into a language of universal generalization, moved from a socially oriented to a metaphysical apperception of the world. During his student days Minskii was closely associated with populist and left-wing groups, and his attempts to publish a socially engaged volume of verse in 1883 were thwarted by the

\footnotetext{
${ }^{2}$ K.A. Kumpan, 'D.S. Merezhkovskii - poet (u istokov “novogo religioznogo soznaniia”)', in D.S. Merezhkovskii, Stikhotvoreniia i poemy, ed. K.A. Kumpan (St Petersburg: Akademicheskii Proekt, 2000), pp. 17-19.

${ }^{3}$ See David N. Wells, 'Merezhkovskii's Simvoly and the Early Development of Russian Symbolism', Australian Slavonic and East European Studies, 23 (2009), pp. 57-67.
} 
tsarist censorship. ${ }^{4}$ His later work takes on more mystical and religious overtones, and indeed his 1887 poem 'Kak son, proidut dela i pomysly liudei' [People's deeds and thoughts pass like a dream], which contrasts the transitory nature of earthly affairs with a vision of a world beyond, was much valued by Aleksandr Blok and by Briusov, who went so far as to call it the first manifesto of Russian Symbolism. ${ }^{5}$ To an extent the career of Nadson himself was marked by a similar trajectory, as the Nekrasov school civic poet of his early work took on the dreamy reflexivity that made him so popular in the 1890 s. $^{6}$

The literary models to which Russian writers of the 1880s looked in order to promote positivist ideas to a striking extent survived the transition to the more idealistic frame of reference provided by Symbolism. A good illustration can be seen in the textual history of Merezhkovskii's verse drama Vozvrashchenie $k$ prirode [Return to Nature], which was based on Calderón's play La Vida es Sueño [Life is a Dream]. Two versions of Merezhkovskii's play are extant. In the original 1888 version, the quest for the meaning of life played out in the main character, Silvio, is resolved in a commitment to hard work for social reform. When Vozvrashchenie k prirode was published in Simvoly, however, Silvio (and Merezhkovskii) no longer saw this outcome as satisfactory, and the revised version ends with a mystical revelation. Silvio acknowledges the power of the divine after he has been persuaded to exercise mercy towards his enemies. The instrument of this persuasion is the character of Estrella, who foreshadows later embodiments in Symbolist poetry of the principle of the 'eternal feminine'. ${ }^{7}$ Calderón, valued initially for his insights into the operation of power by Merezhkovskii the civic poet, came to be esteemed more for his focus on the disjunction and

\footnotetext{
${ }^{4}$ S. Sapozhkov, 'Poeziia i sud'ba Nikolaia Minskogo', in Nikolai Minskii, Aleksandr Dobroliubov, Stikhotvoreniia i poemy, ed. S.A. Sapozhkov and A.A. Korbinskii (St Petersburg: Akademicheskii Proekt, 2005), pp. 8-10.

${ }^{5}$ See Minskii, Dobroliubov, Stikhotvoreniia i poemy, pp. 152-3; Aleksandr Blok, Sobranie sochinenii v shesti tomakh (Moscow: Ogonek, 1971, vol. 5, pp. 225-6; P.P. Pertsov, Literaturnye vospominaniia, 1890-1902 (Moscow: Novoe literaturnoe obozrenie, 2002), p. 176.

${ }^{6}$ See A.M. Bikhter, 'Demokraticheskaia poeziia 1870-1880-kh godov', in Poety-demokraty 1870-1880-kh godov, ed. A.M. Bikhter (Moscow, Sovetskii pisatel', 1962), pp. 15-16, 50.

7 For a detailed comparison of the two versions of Merezhkovsky's drama, see Kumpan, 'D.S. Merezhkovskii - poet', pp. 39-43.
} 
conflict between appearance and reality by Merezhkovskii the Symbolist. For the same reason, Calderón was later to become a source of inspiration in the theatrical productions of Vsevolod Meyerhold and Nikolai Evreinov. ${ }^{8}$

A similar pattern can be seen with the treatment of the Prometheus myth in the writing of transitional authors. In works of the 1880s Prometheus often appears as the champion of oppressed humanity, supporting it through the gift of fire and defending it against the wrath of Zeus, who is portrayed as a tyrannical master. This, for example, is the starting point for Semen Frug's 1885 poem 'Prometeiu' [To Prometheus], in which the lyric persona asserts that the sufferings he himself has to endure in obeying God's command to bring enlightenment to the people are far greater than those of Prometheus, who acted against the wishes of his god. ${ }^{9}$ In 1884 Merezhkovskii wrote a poem, 'Poroi, kak obraz Prometeia' [At times, like the image of Prometheus], in which the speaker contrasts Prometheus' courage with his own cowardice in his approach to social reform. ${ }^{10}$ Merezhkovskii remained interested in this theme and completed a translation of Aeschylus' Prometheus Bound in 1891. When he included the drama in Simvoly, however, the context of the larger work gave this translation a broader significance in asserting the necessity of private space for the cultivation of independent thought separate from the concerns of the mundane world. Treatments by later Symbolists, and in particular Viacheslav Ivanov, extended this metaphysical vision, using Prometheus to point to the redemptive mission of the suffering Christ. $^{11}$

Percy Bysshe Shelley represents another, parallel, meeting point in the literary history of the old and new models of thought. He first became known in Russian translation in 1849,

\footnotetext{
${ }^{8}$ Edward Braun, The Theatre of Meyerhold; Revolution on the Modern Stage (London: Methuen, 1986), pp. 101, 122, 135; Spencer Golub, Evreinov; The Theatre of Paradox and Transformation (Ann Arbor, Mich.: UMI Research Press, 1984), pp. 126-36.

${ }^{9}$ Poety 1880-1890-kh godov, ed. L.K. Dolgopolov (Leiningrad: Sovetskii pisatel', 1972), p. 302.

${ }^{10}$ D.S. Merezhkovskii, Stikhotvoreniia i poemy (St Petersburg: Akademicheskii proekt, 2000), pp. 121-2.

${ }^{11}$ See Robert Bird, The Russian Prospero: The Creative Universe of Viacheslav Ivanov (Madison, Wis.: University of Wisconsin Press, 2006), pp. 153-6.
} 
and continued to receive critical and literary attention in Russia throughout the second half of the nineteenth century and into the twentieth. Awareness of Shelley's work was thus a constant in the literary culture of the period. ${ }^{12}$ Major early contributions to Shelley scholarship in Russia include an 1864 essay by G. Blagosvetlov, which situated the English poet in his literary context and highlighted his significance as an artist and reformer. This essay was followed in 1873 by two articles by M. Tsebrikova which appeared in the populist journal Otechestvennye zapiski and focused particularly on the social and revolutionary aspects of Shelley's writing. ${ }^{13}$ The extensive critical and translation work produced later by Bal'mont in particular, whose rendition of the complete poetical works of Shelley was published in instalments between 1893 and 1899, was fundamental to the interest shown in the English poet in Russia during the 1890s. Shelley continued to attract the attention of poets into the Soviet period as is evident from extensive translations by Boris Pasternak and Samuil Marshak.

Like Calderón and the myth of Prometheus, Shelley appealed in different ways to different constituencies within the field of Russian literature. He was valued by civic writers for the social commitment he showed in his political and anti-religious pamphlets, and for the content of such creative works as Queen Mab with its critique of monarchical government, capitalism and religion, and its promotion of reason and love as the foundations of a glorious future. Petr Veinberg's 1864 translation of The Cenci, seen as a protest against political injustice, was read aloud to groups of peasants by members of the Narodnik movement. ${ }^{14}$ Shorter poems were praised for their revolutionary activism. 'An Ode, Written October 1819, Before the Spaniards had Recovered their Liberty', exhorting the Spanish people (and

\footnotetext{
${ }^{12}$ L. I. Nikol'skaia, Shelli v Rossii: lirika Shelli v russkikh perevodakh XIX-XX vekov (Smolensk: Ministerstvo prosveshcheniia RSFSR, 1972); Rachel Polonsky, 'Revolutionary Etudes: The Reception of Shelley in Russia', in The Reception of P.B. Shelley in Europe ed. Susanne Schmid and Michael Rossington (London: Continuum, 2008), pp. 229-46.

${ }^{13}$ Nikol'skaia, Shelli v Rossii, pp.8-9.

14 Polonsky, 'Revolutionary Etudes', pp. 234-5.
} 
by implication the English) to rise up against their oppressors, is a case in point with its opening line: 'Arise, arise, arise! / There is blood on the earth that denies ye bread'. In works like 'Ode to the West Wind', it was the theme of social change rather than that of personal transfiguration which was emphasized, and the images of spring and the wind itself were presented, in the Russian tradition, primarily as symbols of revolution. ${ }^{15}$ For Symbolist writers, on the other hand, it was Shelley's metaphysical idealism, expressed through the concept of the 'Spirit of Intellectual Beauty', his personifications of natural phenomena, and especially his impressionistic use of language, his extravagant imagery, his rhythmical innovation, and his use of alliteration and assonance, which attracted attention. Bal'mont, especially, was an enthusiastic imitator of both of Shelley's pantheism and of his style.

The ways in which different Russian writers chose to translate Shelley clearly reflect their attitudes to his work. Civic poets like V. Markov and Anna Barykova, while striving to reproduce Shelley's imagery and political dialectic, give relatively little attention to his belief in the unity of all natural things, and in particular to the way in which his language reinforces the thematic content of his poetry. In the opening lines of 'Ode to the West Wind', for example, Shelley combines the solemnity of invocation with a conversational familiarity embedded in the poem's irregular iambic rhythms, enjambements and slightly displaced syntax. One effect of this combination is to foreshadow the 'mutual relation' with the wind sought in the poem's final stanza: 'Be thou me, impetuous one!' 16

A comparison of the beginning of the ode in the original and translated versions will illustrate the differences in approach. Shelley's text reads:

O wild West Wind, thou breath of Autumn's being, Thou, from whose unseen presence the leaves dead Are driven, like ghosts from an enchanter fleeing,

\footnotetext{
${ }^{15}$ Nikol'skaia, Shelli v Rossii, p. 22.

16 Harold Bloom, The Visionary Company: A Reading of English Romantic Poetry (London: Faber and Faber, 1962), p. 292; Percy Bysshe Shelley, The Complete Poetical Works, ed. Thomas Hutchinson (Oxford: H. Milford, 1919), p. 574.
} 
Yellow, and black, and pale, and hectic red,

Pestilence-stricken multitudes. ${ }^{17}$

Markov reproduces the imagery quite accurately, but the much stricter form of his endstopped iambic lines creates a less nuanced and more rhetorical appeal which does not suggest any intimacy between wind and speaker:
О ветер буйный, Осени дыханье!
Неведен ты; но в страхе пред тобой, Как хор теней от слова заклинанья,
Увядших листьев мчится смутный рой, --
Поблекших, желтых, с краскою багровой, Охваченных губительной чумой! ${ }^{18}$

Barykova, choosing a strict dactylic rhythm, creates an even more distancing effect. While evoking the incantations of Russian folklore, she abandons the semi-conversational tone of the original altogether:

Западный ветер, дыханье могучее
Осени! Ты, чьею силой незримою
Мертвые листья, как духи, гонимые
Злым чародеем, проносятся тучею. ${ }^{19}$

The metre here also recalls Lermontov's 'Tuchi' [Clouds] on a similar theme, though the parallel produces something of a misdirection. While in Shelley's ode the poet yearns to merge his voice with that of the wind, Lermontov's cloud exists on a plane completely isolated from human emotion. ${ }^{20}$

Bal'mont, in contrast to both Markov and Barykova, focuses more on reproducing Shelley's tone tan the exact meaning of his words. Even though here he eschews Shelley's

\footnotetext{
${ }^{17}$ Shelley, Complete Poetical Works, p. 573.

18 'Dva stikhotvoreniia Shelli', Otechestvennye zapiski, 1873, no. 5, p. 195.

[O wild wind, breath of Autumn, / you are unknown; but in fear before you / like a chorus of shades from a word of incantation, / flees a troubled swarm of faded leaves, / pale and yellow and crimson, / seized by a destructive plague!]

${ }^{19}$ Cited in Nikol'skaia, Shelli v Rossii, p. 85

[West wind, powerful breath of autumn, / you by whose unseen force / the dead leaves, like spirits pursued / by an evil sorcerer, / are propelled in a cloud]

${ }^{20}$ M.Iu. Lermontov, Polnoe sobranie stikhotovorenii v dvukh tomakh (Leningrad: Sovetskii pisatel', 1989 , vol. 2, p. 56.
} 
use of enjambement, he uses a much less regular iambic line than Markov, and adopts a notably less rhetorical style, without the latter's inversions and exclamations:

О, буйный ветер, Осени дыханье, Перед твоей незримою стопой, Как духи перед властью заклинанья,

Бегут листы, и кружатся толпой, Тая в себе всех красок сочетанье, Объятые губитедьной чумой. ${ }^{21}$

Bal'mont's focus on the overall impact rather than precise semantic content effectively reproduces the frequently chaotic, breathless appeal of Shelley's verse, and in doing so returns to Shelley's central vision of the identity of the wind and the poet.

In 'Ozymandias' Shelley's use of imagery is fairly restrained. The sonnet lacks, for example, the incantatory rhythms and sustained metaphors of 'The Cloud', the mysticism of 'Mont Blanc', and the revolutionary passion of 'Song to the Men of England'. On the other hand it is a work which powerfully exemplifies Shelley's approach to the transformation of experience into poetry, ${ }^{22}$ artfully combines political and metapoetic themes, and in the original, at least, operates at multiple levels of signification. As a result the sonnet conspicuously allows for different emphases in the act of translation depending on the interpretive framework brought to the task by the translator, and provides a touchstone for the different approaches to art taken by Russian writers in the last quarter of the nineteenth century. The detailed analysis of 'Ozymandias' presented here will also provide a valuable analytical tool which might be applied to any subsequent investigation of longer texts in the different interpretations given to them by their Russian translators. ${ }^{23}$

\footnotetext{
${ }^{21}$ Sochneniia Shelli, vyp. 3 (St Petersburg: Stasiulevch, 1895), pp. 51-2.

[O wild wind, breath of Autumn, / before your unseen foot, / like spirits before the force of an incantation, / the leaves run and swirl in a crowd, / blending all colours together, / embraced by a destructive plague]

22 Jean Hall, The Transforming Image: A Study of Shelley's Major Poetry (Urbana: University of Illinois Press, 1980), pp. 19-22.

${ }^{23}$ Michael Wachtel, 'And So - Dante is a Symbolist: The Poetics of Russian Symbolist Translation', in Sankirtos: Studies in Russian and East European Literature, Society and Culture in Honor of Tomas Venclova, ed. Robert Bird, Lazar Fleishman and Fedor Poljakov (Frankfurt: Peter Lang, 2008), pp. 167-85, takes a similar approach in comparing four Symbolist translations of a sonnet by Dante.
} 


\title{
II
}

\section{Shelley's 'Ozymandias'}

\author{
Ozymandias
}

I met a traveller from an antique land

Who said: Two vast and trunkless legs of stone

Stand in the desert... Near them, on the sand, Half sunk, a shattered visage lies, whose frown, And wrinkled lip, and sneer of cold command, Tell that its sculptor well those passions read Which yet survive, stamped on these lifeless things, The hand that mocked them, and the heart that fed:

And on the pedestal these words appear:

'My name is Ozymandias, king of kings:

Look on my works, ye Mighty, and despair!'

Nothing beside remains. Round the decay

Of that colossal wreck, boundless and bare

The lone and level sands stretch far away. ${ }^{24}$

Before considering the translations it will be useful to highlight some features of the original poem. The following draws extensively on the work of Kelvin Everest, who provides perhaps the most comprehensive and nuanced analysis of the sonnet. ${ }^{25}$ On the most obvious level Shelley describes the discovery of a ruined monument to an ancient tyrant, who has long been overthrown and of whose rule there ironically remains little more than an inscription in the middle of a desert asserting his omnipotence. The sonnet form reinforces the succinctness and clarity of this message, while at the same time multiple levels of irony are created through the existence of four competing levels of narration - those of the poet, the traveller, the sculptor, and Ozymandias himself. If the tyrant himself has not survived, it seems that the artistic representation of the tyrant in the fragments of the remaining statue has

\footnotetext{
${ }^{24}$ Shelley, Complete Poetical Works, p. 546

${ }^{25}$ Kelvin Everest, “'Ozymandias”: The Text in Time’, Essays and Studies, vol. 45, no. 1, 1992, pp. 24-42.
} 
outlived its model. Art therefore is arguably stronger than politics, but the fact that the statue now exists only in fragments shows that art itself is subject to decay through the passing of time. Yet precisely because of the survival of the sculptor's work, the tyrant himself also continues to exist in the minds of contemporary observers. And, moreover, for the lesson about the transitory nature of power to carry any weight, it has to be assumed that even if Ozymandias no longer rules his empire there continue to exist other tyrants elsewhere with whom Ozymandias may be compared: even while the individual tyrant is no more, the institution of tyranny necessarily endures.

The measured syntax of the poem, particularly at the beginning and end, reflects the traditions of expository archaeological prose, with a hint of excitement suggested by the frequent enjambement and by the breaking off of the sentence in line three. Lines 6-8, which F.R. Leavis singled out for particular attack in his criticism of Shelley's 'obscurity', ${ }^{26}$ are indeed syntactically problematic, and this section of the poem is also unusual in terms of rhyme. The rhyme scheme is abab acdc edefef with several inexact rhymes. The second quatrain challenges the reader's expectations in that the first line repeats a rhyme from the first quatrain, but this rhyme is not then repeated in the third line, which instead rhymes with the second line of the sestet. Relative to the first quatrain and to the sestet, the second quatrain thus marks a period of instability, which is ultimately resolved, but in the meantime draws attention to the construction of the poem at precisely the point where it discusses the phenomenon of artistic creation. Implicitly then the poem is making a metapoetic statement about its own longevity which may exceed that of both Ozymandias and the sculptor who preserved his memory, but paradoxically may ultimately itself also be subject to decay. As Jean Hall has noted, there are in fact three separate works of art brought to the reader's attention: the statue of Ozymandias, the traveller's story, and the sonnet itself. The same

\footnotetext{
${ }^{26}$ F.R. Leavis, Revaluation:Tradition and Development in English Poetry (Harmondsworth: Penguin, 1972), pp. 191-224.
} 
image is progressively transformed and enlarged over time, in a way suggesting that it will continue to develop through further transformations in the art of the future. ${ }^{27}$

Although Shelley does not make use in 'Ozymandias' of the extensive range of simile and metaphor he employs in other works, he does reinforce its message through the use of rhythmical variation and alliteration: 'cold command' to highlight the tyrant's inflexibility, or 'boundless and bare / The lone and level sands' to emphasise the barren desolation of the desert, which is an apparent consequence of Ozymandias' despotic rule. ${ }^{28}$

\section{III}

\section{Barykova}

\section{Озимандия}

Громадный памятник, былых времен святыня, Стоит в волнах песков безбережной пустыни: Две каменных ноги, высокий пьедестал Полуразрушенный; а рядом впрах упал Безногий истукан с разбитой головою. В лице, воссозданном искусною рукою, В холодных, дышащих презрением чертах, В усмешке злобной и надменной на устах, Застыли жившие в жестоком сердце страсти, Сияет торжество несокрушимой власти. На пьедестале надпись гордая гласит; «Я - Озимандия. Я - царь царей, - великий. Вот рук моих дела! Завидуйте, владыки!» И все безжизненно, все пусто, все молчит Кругом него. Пустыня стелется немая, Осколки прошлого песками засыпая. ${ }^{29}$

27 Hall, Transforming Image, pp. 21-2.

28 See Timothy Morton, 'Nature and Culture', in The Cambridge Companion to Shelley, ed. T. Morton (Cambridge: Cambridge University Press, 2008), pp. 202-3.

${ }_{29}$ A.P. Barykova, Stikhotvoreniia (Moscow, 1910), p. 230, quoted in Nikol'skaia, Shelli v Rossii, pp. 23-4. [Ozymandias. A huge monument, a relic of ancient times, / stands in the waves of sand of the boundless desert: / two stone feet, a tall pedestal / half in ruins; and next to it has fallen to the dust / a footless statue with a broken head. / In its face, captured by an expert hand, / in its cold features, breathing with contempt, / in the malicious and proud smile on its lips, / living passions are frozen in a cruel heart / and the triumph of unconquered power shines out. / On the pedestal resounds the proud inscription: / 'I am Ozymandias. I am the king of kings, the 
The first Russian translation of 'Ozymandias', by Anna Pavlovna Barykova, appeared in 1886. ${ }^{30}$ A collaborator of the radicals A.N. Pleshcheev and P. F. Iakubovich who later aligned herself with Tolstoyan utopianism, Barykova was an original poet in the Nekrasov tradition as well as a translator of numerous works from a wide range of European poets whom she considered to be in tune with the populist social and political agenda. Her approach to translation was in fact explicitly ideological: 'I rarely make concessions to the beauty of form,' she wrote. 'For me the most important things are Feeling and Thought, then Strength of Depiction, while the sound and facility [zvuchnost' i gladkost'] of the verse are only final considerations... They come about or they don't come about ... of their own accord. ${ }^{31}$ Barykova shares here views which were common to many other translators in the civic tradition of the period, notably Mikhail Mikhailov and Petr Veinberg. The main purpose of translation was to popularize content for the benefit of readers who were unable to access it in the original language. Literalism was to be avoided and poetry was to be translated as holistically as possible, with due regard to the impression created by the original work, but the meaning was to be given clear precedence over poetic form. ${ }^{32}$

Accordingly, Barykova treats 'Ozymandias' as an unambiguous allegory with direct application to the position of the Russian autocracy. In order to maintain this focus, she discards much that is distinctive in Shelley's presentation of the material. Most notably, Barykova ignores the perspectives of both the traveller and the sculptor, thus reducing the narrative complexity from four points of view to two, and giving a description of the

great. / These are the works of my hands. Princes, envy me!' / And all is lifeless, all is empty, all silent / around him. The desert stretches out mute / covering the remnants of the past with sand.]

${ }^{30}$ There are also translations by Ch. Vetrinskii (Cheshikhin) and B. Leitin (Nikol'skaia, Shelliv Rossii, p. 24).

31 A.P. Barykova, Stikhotvoreniia i prozaicheskie proizvedeniia (St Petersburg: Posrednik, 1897), pp. 15-16, quoted in Nikol'skaia, Shelli $v$ Rossii, p. 16.

${ }^{32}$ See Iu.D. Levin, Russkie perevodchiki XIX veka i razvitie khudozhestvennogo perevoda (Leningrad: Nauka, 1985), pp. 277-80; E.G. Etkind, 'Poeticheskii perevod v istorii russkoi literatury', in Mastera russkogo stikhotvornogo perevoda, ed. E.G. Etkind (Leningrad: Sovetskii pisatel', 1968), pp.54-6; Maurice Friedberg, Literary Translation in Russia: a Cultural History (University Park: Pennsylvania State University Press, 1997), pp. 50-6. 
decaying statue which is consequently less ambiguous and more authoritative. The multiple levels of irony present in the original have disappeared, leaving an overall clearer statement about the fall of tyranny, which is unlikely to be questioned by the reader. Barykova transfers Shelley's irregular iambic pentameter into a smoother Russian iambic hexameter as the neutral vehicle for this sort of expository verse. She retains a sense of excitement by replicating his enjambements, but also uses metrical features divergent from the original to reinforce the confidence of the poem's message. The irregular cross rhymes of Shelley's octet are replaced by a succession of alternating feminine and masculine couplets, which are not required to reflect any complexity elsewhere in the text, and the last six lines follow a regular emphatic concluding pattern fGGfHH. Ignoring the sonnet form, Barykova allows herself two additional lines in which to expand her description of the statue and its model. Moreover, the language with which she chooses to do this is often more ponderous and explicit than that chosen by Shelley. While the pattern of alliteration and assonance in lines 15-16 does approximate the effect achieved by Shelley in the last two lines of his poem, Barykova introduces, for example, words and indeed whole phrases which are not present in the original. 'Bylykh vremen sviatynia' [relic of ancient times] (line 1) and 'Oskolki proshlogo' [remnants of the past] (line 16), for instance, overdetermine the historical timescale, which Shelley merely alludes to with the word 'antique' in the first line of his sonnet. The lines 'Zastyli zhivshie v zhestokom serdtse strasti / Siiaet torzhestvo nesokrushimoi vlasti' [Living passions are frozen in a cruel heart, / and the triumph of unconquered power shines out] (lines 9-10) serve to explain rather than reproduce Shelley's description of the 'frown / And wrinkled lip, and sneer of cold command' on the tyrant's face. 


\title{
Minskii
}

\section{Озимандия}

Навстречу путник мне из древней шел земли

И молвил: средь песков - минувших дней руина -

Стоят две каменных ноги от исполина,

Лежит разбитый лик во прахе невдали.

Сурово сжатый рот, усмешка гордой власти,

Твердит как глубоко ваятель понял страсти,

Что пережить могли солгавший им язык,

Служившую им длань и сердце - их родник.

\begin{abstract}
А вкруг подножия слова видны в граните:
«Я - Озимандия, великий царь царей.

Взгляните на мои деяния и дрожите!»

Кругом нет ничего. Истлевший мавзолей

Пустыней окружен. Гуляет ветр свободный

И стелются пески безбрежны и бесплодны. ${ }^{33}$
\end{abstract}

Minskii's translation of 'Ozymandias' was first published in 1894. Minskii showed

considerable interest in Shelley throughout his career and also translated Queen Mab and the long philosophical poem Alastor and other shorter works. In his 1882 essay 'Persi Bishi [sic]

Shelli' [Percy Bysshe Shelley], Minskii moves beyond the prevailing view that Shelley is primarily a poet of 'freedom' (svoboda), suggesting that he is better seen as an advocate of 'liberation' (osvobozhdenie) on a personal at least as much as on a social and political plane. He goes on indeed to reflect that while Shelley was driven by a powerful hatred of oppression

\footnotetext{
${ }^{33}$ Minskii and Dobroliubov, Stikhotvoreniia i poemy, p. 236.

[Ozymandias. A traveller from an ancient land came up to me / and said: Among the sands - a ruin of past days - stand two stone feet from a giant, / a broken face lies in the dust nearby. // The mouth compressed sternly, the smile of proud power / show how deeply the sculptor understood the passions / which could outlive the tongue that lied to him, / the hand that served him, and the heart that was their source. // And around the pedestal these words can be seen in the granite: 'I am Ozymandias, the great king of kings, / look on my deeds and tremble!' // Around is nothing. The decaying mausoleum / is surrounded by desert. A free wind blows / and the sands spread out, boundless and sterile.]
} 
in all its forms, he did not in fact have a consistent or coherent conception of political or social freedom as such. Minskii pays particular attention to Shelley's language, noting that it harmonises with the content of his writing: 'His phrasing is elegant and bright, like a marble column around which his thought is entwined like pure fire disappearing into the sky. Only reading Shelley do you realize how much rhetoric and bluster there is in Victor Hugo'. ${ }^{4}$

Minskii's version of 'Ozymandias' reflects his early social and political commitment, but at the same time demonstrates an awareness of Shelley's metatextual reflexivity. It follows the dramatic and verse structure of Shelley's poem significantly more closely than does Barykova's version, allowing the multiple ironies of the original to appear at least in part. The framing structure of the traveller is thus retained, as is the explicit presence of the sculptor. The poem is written in an approximation of Shakespearean sonnet form in iambic hexameter and retains Shelley's use of enjambement to create a forward movement. It lacks the instability produced by Shelley's distinctive rhyme scheme, but replicates the complexity of Shelley's syntax of lines 6-8 in the same lines of the translation. These lines differ in their impact from the original in that the emphasis on the act of creativity produced by 'The hand that mocked them' is displaced in Minskii's translation by the introduction of an additional narrative voice - that of the tyrant's subjects, those who pandered to his vanity and those who served him and thus preserved him in power: 'Chto perezhit' mogli solgavshii im iazyk, / Sluzhivshuiu im dlan' ...' [which could outlive the tongue that lied to him, / the hand that served him...]. This interpretive passage highlights one particular possible understanding of the role of Shelley's sculptor: for all the contempt of his attitude to Ozymandias implied by the double sense of the word 'mocked' in line 8 (both 'derided' and 'copied'), he is nevertheless responsible for the promulgation of Ozymandias' image and power. Minskii's emphasis on Ozymandias' oppressed subjects foreshadows his use at the end of the poem of

${ }^{34}$ N. Minskii, 'Persi Bishi Shelli', Zagranichnyi vestnik, 1882, no. 2, pp. 47-61 (57). 
the expression 'Guliaet vetr svobodnyi' [a free wind blows], which is not directly justified by Shelley's text, but which both evokes the 'unylyi peizazh' [melancholy landscape] of the Nekrasov tradition, and hints at the political significance of the motif of the wind established in 'Ode to the West Wind', and reflected in later Russian revolutionary writing. ${ }^{35}$ Like Barykova, Minskii also stresses the notion of the past to an extent not present in Shelley's text. His use of 'drevnii' [ancient] in line 1 is extended first of all by the inverted syntax of the sentence in which it occurs. This departure from everyday syntax gives the phrase an antiquarian quality, which is then extended by the expressions 'minuvshikh dnei riuna' [ruin of past days] (line 2) and 'mavzolei' [mausoleum] (line 12), the total effect being to imply that Russian tyranny will soon be just as distant a memory as that of Ozymandias. While taking a much subtler approach to the complex ironies and structures of Shelley's verse than Barykova, Minskii thus remains equally focused on its application in the Russian context.

\section{Bal'mont}

\section{Озимандия}

Я встретил путника; он шел из стран далеких

И мне сказал: вдали, где вечность сторожит

Пустыни тишину, среди песков глубоких

Обломок статуи распавшейся лежит.

Из полустертых черт сквозит надменный пламень -

Желанье заставлять весь мир себе служить;

Ваятель опытный вложил в бездушный камень

Те страсти, что могли столетья пережить.

\footnotetext{
${ }^{35}$ See Nikol'skaia, Shelliv Rossii, p. 17. The action of Shelley's west wind is also associated with the advent of spring ('If Winter comes, can Spring be far behind?'), and Minskii may thus also be indirectly alluding to the association between spring and social reform found in such civic verse of the period as Vasilii NemirovichDanchenko's 'Rodnoi krai': 'Ia vas poiu, tainstvennye sily, / Poiu vesnu i solntse luchshikh dnei... / Otkroiutsia zabytye mogily; / Voskresnet zhizn' na rodine moei...' [I sing of you, secret forces, I sing of the spring and the sun of better days... Forgotten graves will open; life will rise up in my homeland], Poety-demokraty 1870-1880kh godov, ed. V.G. Bazanov, B.L. Bessonov and A.M. Bikhter (Leningrad: Sovetskii pisatel', 1968), p. 615.
} 


\title{
И сохранил слова обломок изваянья: \\ «Я - Озимандия, я - мощный царь царей! \\ Взгляните на мои великие деянья, \\ Владыки всех времен, всех стран и всех морей!»
}

\author{
Кругом нет ничего... Глубкое молчанье... \\ Пустыня мертвая... И небеса над ней... ${ }^{36}$
}

Bal'mont immersed himself in Shelley to a quite unusual extent, thoroughly incorporating his work, as Martin Bidney has noted, 'into his own creative and critical processes'. As well as translating the whole of Shelley's verse he left extensive annotations to his translations, wrote critical essays on Shelley, used epigraphs from Shelley extensively, wrote poems about Shelley, and imitated Shelley's style in his own work. ${ }^{37}$ Like other Symbolists, Bal'mont took a view of translation quite different from the positivist writers, focusing rather more on form and language than on content, and drawing no real distinction between the expression of his 'personal and aesthetic philosophy' in his original and translated works. ${ }^{38}$ He consistently read and interpreted Shelley in the light of his own Symbolist convictions, so much so that his translations came to be unjustly castigated as 'Shel'mont'. 39

Certainly, the emphasis in Bal'mont's essays on Shelley is very different from that of earlier commentators. The themes of freedom and social justice are largely ignored, and instead Bal'mont presents Shelley as an otherworldly visionary whose creativity transcended

${ }^{36}$ K.D. Bal'mont, Stikhtovoreniia (Leningrad: Sovetskii pisatel', 1969), p. 502.

[Ozymandias. I met a traveller. He came from distant lands / and said to me: Far away, where eternity guards / the silence of the desert, amid the deep sands / lies the fragment of a broken statue. // A haughty flame shows through the half-erased features -- / the desire to make all the world obey him; / the experienced sculptor put into the soulless stone / passions which could survive centuries. // And a fragment of the sculpture preserves the words: / 'I am Ozymandias. I am the mighty king of kings! / Look at my great works, / you rulers of all times, all countries and all seas!' // Around there is nothing... A deep silence... / A dead desert... And the heavens above it...]

${ }^{37}$ Martin Bidney, 'Shelley in the Mind of the Russian Symbolist Bal'mont: Six Kinds of Influence/Appropriation', Comparative Literature Studies, vol. 25, no. 1, 1988, pp. 57-71 (57); see also Rachel Polonsky, English Literature and the Russian Aesthetic Renaissance (Cambridge: Cambridge University Press, 1998), pp. 69-96.

${ }^{38}$ Etkind, 'Poeticheskii perevod', p. 61.

39 K.I. Chukovskii, Sobranie sochinenii v shesti tomakh, vol. 3 (Moscow: Khudozhestvennaia literatura, 1966), p. 260; cf. E. Etkind, Poeziia i perevod (Moscow: Sovetskii pisatel', 1963), pp. 89-90; A.S. Ivanova, K.D.

Bal'mont-perevodchik angliiskoi literatury (Ivanovo: Episheva, 2009), p. 75. 
everyday life and brought the whole of existence into a revelatory harmony: 'Shelley saw in himself a rich world, isolated from other worlds as a star is separate from other stars, but like a star he mixed his rays with the radiance of other heavenly bodies, and his all-encompassing soul, while aware of its own completeness, at the same time felt itself to be part of a harmonious infinite whole'. ${ }^{40}$ For Bal'mont, Shelley's life and work were part of an allembracing unity which exemplified the Symbolist notion of 'zhiznetvorchestvo' (life creation), and made Shelley a moral example of the true Poet. ${ }^{41}$

Bal'mont's version of 'Ozymandias' was published in the first instalment (vypusk) of his complete translation of Shelley's works in 1893. Like Minskii, he retains Shelley's four narrative voices and thus to a large extent preserves the ironic complexity of the original. In many respects, however, the exposition has been simplified. The rhyme scheme for example is very regular - three quatrains with crossed alternating masculine and feminine rhymes followed by a couplet repeating the final rhymes of the third quatrain. The use of enjambement has been limited to the first quatrain, and is confined to the description by the traveller of his discovery of the statue. As in Minskii, but without the intertwining of sense groups found in Shelley's original, each rhyme group contains a distinct idea - 1) discovery of the statue, 2) the role of the sculptor, 3) the inscription on the pedestal, 4) reflection on the passing of time. To achieve this within the structure he has chosen, Bal'mont has expanded the text of the inscription from two lines to three. In doing this he amplifies the designation of the addressee from 'ye Mighty' to 'vladyki vsekh vremen, vsekh stran i vsekh morei' [you rulers of all times, all countries and all seas], losing concision but emphasising the scope of Ozymandias' ambitions. At the same time he has chosen not to convey the injunction to 'despair', which seems to weaken the sense of arbitrary rule conveyed in the original and in the other translations.

\footnotetext{
40 K.D. Bal'mont, 'Prizrak mezh liudei', in his Gornye vershiny: sbornik statei (Moscow; Grif, 1904), p. 134.

41 N.A. Molchanova, Poeziia K.D. Bal'monta 1890-kh-1910-kh godov: problema tvorcheskoi evoliutsii (Moscow: MGPU, 2002), p. 27.
} 
Although Bal'mont includes in his description of the statue the phrase 'Zhelan'e zastavliat' ves' mir sebe sluzhit" [the desire to make all the world obey him], which is an explicit clarification of Ozymandias' ambition, unlike Barykova or Minskii he does not emphasise the possible application of Shelley's poem to the nineteenth-century Russian context. There is, moreover, no reference to the wind of change, and indeed no sustained reference to the past or to the historicity of the past as in the other translations. Shelley's reference in the first line to 'an antique land' is replaced in Bal'mont's version by a spatial allusion: 'iz stran dalekikh' [from distant lands] and the following explicit time reference (in line 2) is also qualified by reference to space: 'vdali, gde vechnost' storozhit' [far away where eternity guards]. This change gives the poem a rather abstract focus, which is emphasised by the description of the statue as an 'oblomok' [fragment] and omission of the separate parts of the statue mentioned by Shelley, and by the strikingly impressionist syntax of the final two lines describing the immensity and barrenness of the desert - four verbless sentences all broken off with three dots. Partly because he minimises the political implications of the poem, Bal'mont's treatment of the metapoetic theme comes to the fore. 'Vaiatel' opytnyi vlozhil v bezdushnyi kamen' / Te strasti, chto mogli stolet'ia perezhit" [the experienced sculptor put into the soulless stone / passions which could survive centuries] is a clear statement in the Symbolist tradition of the leading role of the artist. Because of the change in syntax the last two lines can be ascribed not to the traveller (as seems the most likely attribution in the original), but to the poet, and they thus become primarily a meditation on the supremacy of art, which survives any of the objects from which it draws its inspiration.

\section{VI}

The three different translations of Shelley's 'Ozymandias' reveal a considerable range of interpretive response - from the largely utilitarian treatment of Barykova, through the more 
nuanced approach of Minskii, which combines promotion of the political theme with a more sophisticated awareness of the multiple perspectives of Shelley's poem, to the appropriation of Shelley to the Symbolist world view championed by Bal'mont. Further comparison of individual texts would certainly confirm Shelley's role as a catalyst in expressing a range of radically different aesthetic views, and indeed Russian poetry of the late nineteenth century could productively be categorised in terms of its response to Shelley's work.

The example of Shelley also confirms that the literary world of the 1880s and 1890s in Russia was a particularly fluid space in which multiple overlapping trends competed for the attention of readers. Within this space, both the older, socially oriented writers and the adherents of the new more idealistically focused Symbolism show a deep-rooted respect both for literary models in the past and for the works of foreign writers, and in many cases the sources of inspiration are the same. From this point of view, Symbolism is not so much a break with the literary establishment as a redirection of a shared culture towards ends that are generalized, universal and metaphysical rather than specifically and concretely rooted in the Russian actuality of the day. While Russian Symbolism was to take the literary world a long way beyond the civic verse of the 1880s in the sophistication of its aesthetic sensibilities and its willingness to embrace new visions of the world and new forms of artistic expression, its origins lie to a large extent in the same literary traditions. Comparing the different treatments of Shelley at the time Symbolism was emerging as a movement provides a salient illustration of this process of transformation. 